\title{
THE RELIGIOUS STRUCTURAL EVOLUTION OF THE APUSENI MOUNTAINS
}

\author{
Mădălin-Sebastian LUNG *
}

Ph.D. Student, Babeș-Bolyai University, Doctoral School of Geography, Faculty of Geography, Clinicilor Street, 5-7, 400006, Cluj-Napoca, România, e-mail: 1ungmadalin@yahoo.com

\section{Gabriela-Alina MUREȘAN}

Babeș-Bolyai University, Faculty of Geography, Clinicilor Street, Nr. 5-7, 400006, Cluj-Napoca, Romania, e-mail: alina.muresan@ubbcluj.ro

Citation: Lung, M.-S., Mureșan, G.-A. (2020). The Religious Structural Evolution of the Apuseni Mountains. Revista Română de Geografie Politică, 22(2), 107-120. https://doi.org/10.30892/rrgp.222107-341

\begin{abstract}
This paper aims to analyse the religious structure and its evolution in the Apuseni Mountains (Romania). Thusly, we employed statistical data from three distinct population censuses, the first one being the Austro-Hungarian census of 1880 . The next one was the one in 1930, organised by Romanian authorities. Furthermore, it was the first and most important demographic census after the Great Union of 1918. The last census taken into consideration was the one in 2011 , the second census of the $21^{\text {st }}$ century. After obtaining the numerical data from the three censuses, we processed it using Microsoft Excel. Three tables were generated, emphasizing the numerical values and the percentages for each religion or confession for each census. The map depicting the geographic location of the study area was developed using GIS technology (ArcGis 10.3). We determined that Christians have been dominating the Apuseni Mountains and the Orthodox faith had and still has the most adherents. Likewise, the political-administrative factor heavily influenced census operations and also produced imbalances in the religious structure, especially after the 1948 abolition of the monarchy.
\end{abstract}

Key words: religious structure, evolution, Apuseni Mountains, Romania, censuses

$$
* * * * * *
$$

\section{INTRODUCTION}

This study aims to create an analysis of the religious structural evolution of the Apuseni Mountains, employing data from three separate population censuses. The first census we used was the one in 1880 , organised by the Austrian-Hungarian authorities. The second census we used was the one in 
1930, which was the first and most important demographic study after the historical moment of the 1918 Great Union. The last census utilized was the one in 2011 , the second population census of the $21^{\text {st }}$ century. Moreover, we aim to identify certain causes which led to increases or decreases in different religious communities, from one census to another.

The study of religions/confessions is a well established and researched field in Romania. For Banat, Transilvania, Crişana and Maramureș, the religious phenomenon has been studied alongside other phenomena, such as ethnicity and electoral behaviour (Bodocan, 2001; Crețan, 1999; Ilieș, 1998, Ilieș et al., 2020). Other studies focused on the religious structure of Mureș County in 2011 (Tofan, 2014), as well as Covasna, Harghita and Mureș counties as a whole (Tofan et al., 2014), and the concurrent study of ethnicity, religion and electoral behaviour in Covasna, Harghita and Mureș counties between 2008-2014 (Tofan, 2015). Another engaging study was focused on ethnicity, religion, and marriage in north-western Transylvania (Şişeştean, 2002). A simultaneous look on religion and ethnicity in Petroșani Depression emphasized an ethnical and religious continuity between 1850-2011 (Lung, 2019), respectively the study of ethnicity and religions in mining centres in the Banat Mountains (Lung and Mureșan, 2020). Religious structure has been carefully investigated, from multiple perspectives, by various researchers from many other countries (Basedau et al., 2011; King and Furrow, 2004; Menjivar, 1999; Meyer, 2009; Olajubu, 2004; Olson et al., 2006; Pollard, 2009; Todd and Allen, 2011; Weightman, 1993; Williams and Wright, 2015; Wilson and Janoski, 1995).

\section{STUDY AREA}

Apuseni Mountains are part of the Western Carpathians, as well as a component of the Romanian Carpathians. They include areas from six different counties: Alba, Arad, Bihor, Cluj, Hunedoara, and Sălaj. From an administrative standpoint, Apuseni Mountains comprise 153 territorial units, 140 being communes (rural areas), while 13 are classified as towns and cities (urban areas). In order to devise a better territorial analysis, we divided the space of the Apuseni Mountains into six regional subsystems: Alba Apuseni, Arad Apuseni, Bihor Apuseni, Cluj Apuseni, Hunedoara Apuseni and Sălaj Apuseni.

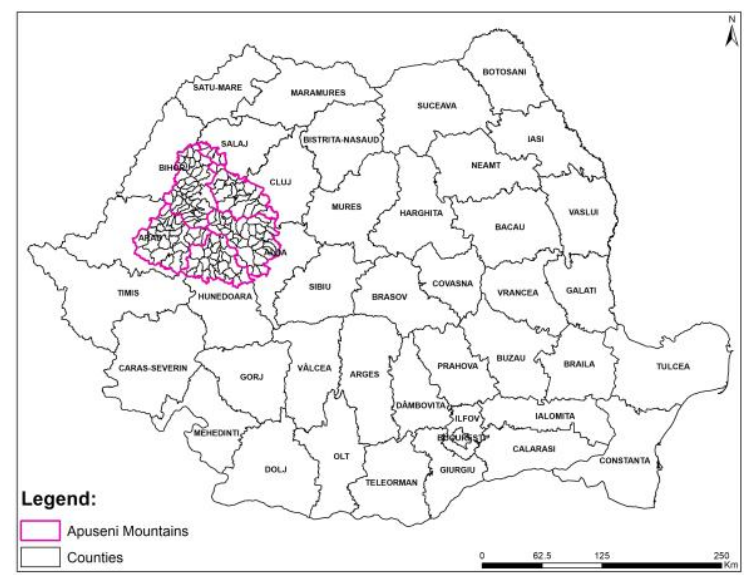

Figure 1. Geographic location of Apuseni Mountains

(Source: own study) 


\section{METHODOLOGY}

The statistical data needed for our study is part of population census 1880 (Rotariu et al., 1997), 1930 (Rotariu et al., 2011), 2011 (NIS). Data was later processed using Microsoft Excel, which generated tables for each census we used. We utilized GIS technology (ArcGis 10.3) to generate the map for the location of the Apuseni Mountains (figure 1) and to make maps with the distribution of religions/confessions for each administrative-territorial unit.

\section{RESULTS AND DISCUSSIONS}

Religious structure of the Apuseni Mountains at the 1880 census

At the 1880 census (table 1, figure 2), two major religions were registered in Apuseni, Christian and Judaism. However, this result is rather strange as no person of Jewish ethnicity has been registered at that census, but 4.900 people were registered as having a Judaic religion.

Table 1. Religious structure in the Apuseni Mountains at the 1880 census (Source: data processed based on Rotariu et al., 1997)

\begin{tabular}{|c|c|c|c|}
\hline Religions & Religious denominations & Total number & Percentage \% \\
\hline \multirow{3}{*}{ Christian } & Orthodox & 366.217 & 76 \\
\cline { 2 - 4 } & Greek-Catholic & 67.521 & 14.01 \\
\cline { 2 - 4 } & Roman-Catholic & 16.648 & 3.45 \\
\cline { 2 - 4 } & Reformed (Calvinist) & 23.022 & 4.78 \\
\cline { 2 - 4 } & Evangelical (Lutheran) & 514 & 0.11 \\
\cline { 2 - 4 } & Unitarian & 3.014 & 0.63 \\
\hline Jewish/Mosaic & & 4.900 & 1.02 \\
\hline Other & & 35 & 0.01 \\
\hline
\end{tabular}

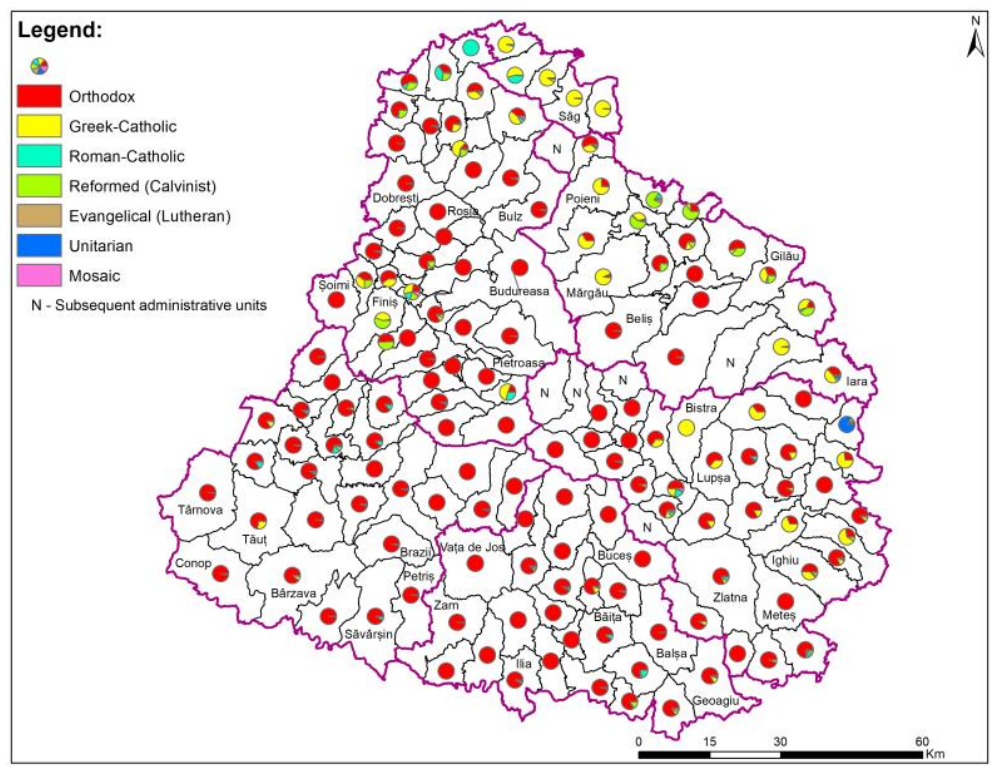

Figure 2. Distribution of religions/confessions for each administrative-territorial unit in 1880

(Source: data processed based on Rotariu et al., 1997) 
Orthodox was the largest group - $76 \%$, (at the 2011 census it had already reached 80\%). Besides Orthodox, other denominations include: Greek-Catholics - $14.01 \%$, Reformed - $4.78 \%$ and Roman-Catholic - 3.45 \%.

Despite having 4.900 registered Jewish/Mosaic adherents, their regional percentage was only $1.02 \%$.

Four anomalies were recorded at local levels in terms of Orthodox territorial distribution - no Orthodox registered in four administrative-territorial units. It is the case of Șinteu commune from Bihor Apuseni as well as Halmășd, Sâg and Valcău de Jos in the Sălaj Apuseni. Likewise, four administrative units recorded 100 \% Orthodox adherents (Ștei from Bihor Apuseni, Blăjeni and Bulzeștii de Sus from Hunedoara Apuseni, Mărișel and Râșca in Cluj Apuseni).

The second most important religious group in Apuseni was Greek-Catholic, having a homogenous distribution within this mountain region, in larger or smaller local communities. Greek-Catholics were predominant in 20 territorial units (Băișoara, Beiuș, Bistra, Borod, Cizer, Galda de Jos, Gilău, Halmășd, Iara, Întregalde, Livezile, Mărgău, Nucet, Plopiș, Poieni, Poșaga, Săcuieu, Sâg, Vadu Crișului, and Valcău de Jos). Therefore, areas with major Greek-Catholic presence and influence were found in Alba, Cluj and Sălaj Apuseni. Moreover, there were significant Greek-Catholic communities in Bihor Apuseni, while in Arad and Hunedoara Apuseni this denomination had an insular characteristic. The greatest majorities were recorded in units from Sălaj Apuseni, with percentages above $90 \%$ in four communes (Cizer $97 \%$, Halmășd 96 \%, Sâg 97 \%, Valcău de Jos 91 \%). The largest Greek-Catholic community was in Mărgău Cluj Apuseni, 3.562 people.

The majority of the Reformed denomination was located in Cluj and Bihor Apuseni, two communes from these areas managing to maintain a strong continuity until the 2011 census. Thusly, the communes of Izvoru Crișului and Sâncraiu from the Cluj Apuseni had been dominated by Reformed adherents for the entire period. At the 1880 census, Reformed constituents reached $64 \%$ in Izvoru Crișului and $59 \%$ in Sâncraiu. Their representation continued to gradually increase until 2011. Three other territorial units held a vast majority of Reformed: Finiss and Huedin with $56 \%$ and $78 \%$ respectively, while the difference between Reformed and Greek-Catholics in Săvădisla was only three percentage points (39, respectiv $36 \%$ ).

The fourth largest religious group of the Apuseni Mountains was RomanCatholic, dominating Șinteu (99\%) and having a strong presence in Aleșd (38 \%) in Bihor Apuseni. In S,inteu, the Slovak community declared itself as RomanCatholic, as did the Hungarian community of Aleșd. Roman-Catholic communities with more than 1.000 people were also recorded in Certeju de Sus, Roșia Montană and Plopiş, where Roman and Greek- Catholics reached percentages of $44 \%$ and $54 \%$.

An exceptional case was the Unitarian community of Rimetea commune, Alba Apuseni, the only administrative unit in the Apuseni Mountains with a Unitarian majority - $84 \%$. This denomination succeeded in preserving its faith for the entire period at hand and it remains the only case in Apuseni Mountains where Hungarians adopted Unitarianism.

Jewish communities were scattered and small, the majority being comprised of less than 100 people. This religious group was poorly represented in Sălaj Apuseni, with only 297 recorded people. The largest subregional community however was found in the Bihor Apuseni, with 1.545 Jewish 
adherents, followed by communities in the Arad Apuseni with 1.003 people, Cluj Apuseni - 984, Hunedoara Apuseni - 617 and Alba Apuseni - 454.

\section{Religious structure of the Apuseni Mountains at the 1930 census}

At the 1930 census (table 2, figure 3), the religious structure of the Apuseni was divided into Christian and Judaism. The most extensive was the Christian faith, with several well established denominations scattered across the region.

There were 436.891 Orthodox believers, meaning a value of $73.57 \%$ of the entire population. However, there were several anomalies in its distribution in 23 administrative-territorial units (Băișoara, Bistra, Borod, Cizer, Finiș, Galda de Jos, Halmășd, Huedin, Izvoru Crișului, Întregalde, Livezile, Mărgău, Plopiș, Poieni, Rimetea, Săcuieu, Săvădisla, Sâg, Sâncraiu, Şinteu, Uileacu de Beiuş, Vadu Crișului, Valcău de Jos); thusly, Orthodox adherents did not form the majority in these areas, being the second most numerous community. The largest Orthodox local community was located in the Arad Apuseni, with a total of 10.767 in the commune of Târnova. In contrast, two communes, Sinteu from the Bihor Apuseni and Halmășd from Sălaj Apuseni, recorded 9 and respectively 8 registered Orthodox. In 1930, there were three 100 per cent Orthodox communes (Blăjeni, Bulzeștii de Sus, Ceru-Băcăinți).

The Greek-Catholic community registered 89.265 people, or 15.03 \%. 16 administrative units did not record a single Greek-Catholic adherent in 1930 (Blăjeni, Brazii, Bulzeștii de Sus, Câmpani, Ceru-Băcăinți, Dieci, Hălmăgel, Ignești, Lazuri de Beiuş, Luncoiu de Jos, Poiana Vadului, Pomezeu, Râmeț, Ribița, Tomești, Vadu Moților). The commune of Poieni from the Cluj Apuseni had the largest Greek-Catholic community, comprised of 6.119 people. GreekCatholic were generally located in the Cluj and Sălaj Apuseni mountains, where they had established large communities. $49.99 \%$ of the total number of GreekCatholics lived in the 23 administrative units of these two areas. $31.89 \%$ were found in the settlements of the Cluj Apuseni and $18.10 \%$ in Sălaj Apuseni. Greek-Catholics also formed religious majorities in 15 territorial units (Băișoara, Bistra, Borod, Cizer, Galda de Jos, Halmășd, Întregalde, Livezile, Mărgău, Poieni, Săcuieu, Sâg, Uileacu de Beiuș, Vadu Crișului, Valcău de Jos).

The Apuseni Mountains witnessed several religious mutations at the end of the $18^{\text {th }}$ century and beginning of the 19 th century. The Greek-Catholic majority recorded in Mărgău, at the 1930 census, took shape as numerous Orthodox Romanians converted to Greek-Catholicism. The event took place in 1774, during the canonical visit of Bishop Grigore Maior to Someș Valley. The bishop's visit took place between 10th August and 10 $10^{\text {th }}$ September, during which 40 villages converted to the Greek-Catholic faith. As a sign of gratitude, Grigore Maior raised Mărgău Parish at the rank of archpriestship in 1780. The Greek-Catholic community thrived until 1948, the dawn of the communist era foreshadowing confessional mutations. In 1948, the Greek-Catholic population was reconverted to Orthodoxism, as the Greek-Catholic church faced persecution (SSematismul veneratului cler al Archidiecesei metropolitane greco-catolice române de Alba-Iulia şi Făgăraş pre anul Domnului 1900 : de la Sânta Unire 200).

Reformed (calvinists) had the third largest population at the 1930 census. Reformed communities registered $4.94 \%$ in the Apuseni Mountains, their total number reaching 29.308 adherents. 25 administrative units did not register any Reformed whatsoever. But they formed the majority in five units (Finiș, Huedin, Izvoru Crișului, Săvădisla, Sâncraiu). Large Reformed communities with more 
than 1.000 people were recorded in three other areas (Aleșd, Căpușu Mare, Tărcaia). Thusly, one can observe that the largest and best structured Reformed communities were located in the Bihor and Cluj Apuseni Mountains.

The total number of Roman-Catholics was 21.300 people, with a percentage of $3.59 \%$. Only four administrative units registered Roman-Catholics communities with more than 1.000 people (Borod, Plopiș, Silindia, Șinteu). In Plopiș commune from Sălaj Apuseni and Șinteu from Bihor Apuseni, RomanCatholics formed the majority. 22 administrative units did not record any Roman-Catholics at the 1930 census.

Baptists recorded $1.34 \%$, with a total of 7.975 adherents. Most Baptist communities had fewer than 100 people, missing from only 31 territorial units. Dieci commune, located in Arad Apuseni had the largest Baptist community in the entire Apuseni Mountains, with 582 people. In 1930, 59.16 \% of the entire Apuseni Baptist population was located in the Arad Apuseni.

The First World War was the main factor which influenced the territorial diversification of the Baptist community. Many soldiers had returned from the front already converted to Baptism. Up to the war, Baptists were mostly found in urban areas, but the war itself created the premises for the denomination to geographically spread out across rural areas. The war basically and decisively influenced the collective demographic mentality, by creating a framework of acceptance and expansion of new religions, such as Baptism. The main missionaries of this denomination were the soldiers who returned to their homes after the war, and who were adamant that this religion might be suitable for creating a better life. The faith spread by converting family members, neighbours, as well as acquaintances. When this was done, church members went to preach in other settlements far and wide (Bodeanu, 2009, pp. 53-55).

Unitarians reached $0.46 \%$, and a population of 2.759 people. This denomination was found in 38 administrative units, the largest community being in Rimetea, Alba Apuseni. The Unitarians of Rimetea registered $70.46 \%$ of the total number of unitarians in the entire Apuseni Mountains. The second largest Unitarian community was Iara, but with fewer adherents than in Rimetea, only 430 people.

There were 590 Evangelicals in the Apuseni Mountains, that is a percentage of $0.10 \%$. The largest Evangelical - Lutheran community was in Geoagiu, the Hunedoara Apuseni, with a total of 140 adherents at the 1930 census. Despite its fewer numbers in the Apuseni, Lutherans were present in 67 administrative-territorial units. In many such units, there were fewer than five adherents per unit.

Adventists was the least represented faith in the Apuseni Mountains at this particular census. Only 122 Adventists were recorded and the largest Adventist community was the one in Târnova, the Arad Apuseni, with 30 people. Their percentage was solely $0.02 \%$. However, Adventists were recorded in 20 administrative units in the Apuseni Mountains, many settlements with fewer than 3 people.

Jewish communities formed a regional populational mass of 5.610 people. They were rather evenly distributed at a regional level, in smaller or larger communities. The largest Jewish community was located in the Cluj Apuseni, in the town of Huedin. Here, there were 1.026 adherents in 1930, $18.29 \%$ of the entire regional community. Jews were not found and recorded in 35 
administrative units. Judaism held a $0.95 \%$ in the religious structure of the Apuseni Mountains at the 1930 census.

This regional community was broken in 1942. The Jews from Huedin were first deported to Baia-Mare, and to Russia and the Ukraine in 1943. The final deportation of Huedin Jews began on 3rd May 1944, when all adherents were taken to the camps of Birkenau-Auschwitz in Poland. Deportations took place across the entire Huedin area and it is believed that roughly 1.200 people were taken to the camps, only around 100 surviving the war and later settling in Israel (Filip \& Matiș, 2014, p. 326).

Table 2. Religious structure of Apuseni Mountains at the 1930 census (Source: data processed based on Rotariu et al., 1997)

\begin{tabular}{|l|l|l|l|}
\hline Religions & Religious denominations & Total & Percentage (\%) \\
\hline \multirow{5}{*}{ Christian } & Orthodox & 436.891 & 73.57 \\
\cline { 2 - 4 } & Greek-Catholic & 89.265 & 15.03 \\
\cline { 2 - 4 } & Reformed (Calvinist) & 29.308 & 4.94 \\
\cline { 2 - 4 } & Roman-Catholic & 21.300 & 3.59 \\
\cline { 2 - 4 } & Baptist & 7.975 & 1.34 \\
\cline { 2 - 4 } & Unitarian & 2.759 & 0.46 \\
\cline { 2 - 4 } & Evangelical (Lutheran) & 590 & 0.10 \\
\cline { 2 - 4 } & Adventism & 122 & 0.02 \\
\hline Jewish & & 5.610 & 0.95 \\
\hline
\end{tabular}

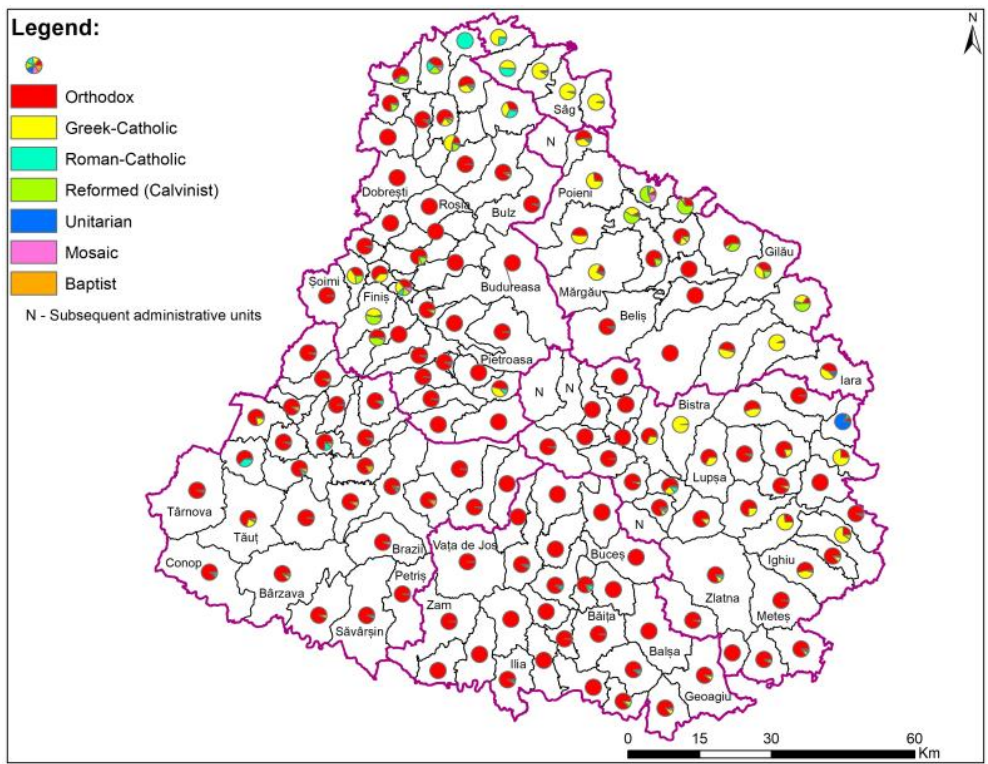

Figure 3. Distribution of religions/confessions for each administrative-territorial unit in 1930 (Source: data processed based on Rotariu et al., 1997)

The 1918 Union also brought some corrections in terms of the local religious structures found in the Apuseni Mountains. Thusly, at the first census conducted by Romanian authorities, in 1930, every administrative-territorial unit had an Orthodox community. It was the time for the millenial Orthodox tradition of the Apuseni to be fully reinstated. Compared to 1880, a new 
denomination was registered in 1930 (Baptists), with a relatively high number of followers. Other religious changes proved inconsequential compared to 1880 . Religious dysfunctionalities would appear only after 1948, when the monarchy was abolished and replaced by a socialist regime.

\section{Religious structure of the Apuseni Mountains at the 2011 census}

At the 2011 census (table 3, figure 4), the religious structure of the Apuseni was more diverse, divided into three major religions: Christian, Muslim, and Judaism. Christians expanded across this vast space as new denominations began to emerge, especially after the fall of communism in 1989.

The percentage of Orthodox was higher than in 1930, reaching $83.69 \%$, as a continuous christalisation of Orthodoxism began to gradually take place in the Apuseni. If in 1930 only three administrative units were $100 \%$ Orthodox, at the 2011 census, their number increased to five (Ceru-Băcăinți, Ocoliș, Ponor, Râmeț, Scărișoara). All of these settlements are located in the Alba Apuseni, mirrroring the massive Romanisation and Orthodox christianisation of the Central Apuseni. Another aspect that must be taken into account is the significant decrease of areas where the Orthodox faith did not occupy first place in the religious roster at the 1930 census. Therefore, from 23 administrative units in 1930, it went to just 4 in 2011, as they had preserved their religious structure - Izvoru Crișului, Săvădisla, Sâncraiu, Şinteu. The religious and ethnic structure of the first three communes is dominated by Hungarians, while Șinteu by Slovaks.

The second denomination was surprinsingly the Pentecostals, with a value of $5.88 \%$ and a total number of followers of 22.539. It is without a doubt the denomination with the sharpest increase. The largest Pentecostal community in the Apuseni Mountains was recorded in Târnova from the Arad Apuseni, with 1.471 people. The next large local Pentecostal community is located in the Bihor Apusenii, Dobrești commune, with 1.393 followers. These are the only Pentecostal communities with more than 1.000 members. There are however several local communities between 300-1.000 people. In 24 administrative units, there was no record of any Pentecostal adherent.

The Reformed denomination had lost by $2011,43.79 \%$ of its entire regional population, reaching $4.30 \%$. There were 7 administrative units with more than 1.000 members (Aleșd, Căpușu Mare, Finiș, Huedin, Izvoru Crișului, Săvădisla, Sâncraiu). Reformed form a majority in the last three areas. In Izvoru Crișului and Sâncraiu, both located in Cluj Apuseni, the Reformed community registered $80 \%$ of the total population, which entails a strong rooting in the area. Huedin has the largest Reformed community in the Apuseni Mountains, with 2.484 people. These three administrative units basically form the largest Reformed core, the administrative proximity being beneficial to the establishment of this religious community. The largest subregional Reformed community was located in the Cluj Apuseni, recording at the 2011 census 56.38 $\%$ of the entire regional mass. The smallest communities were recorded in the Sălaj Apuseni, with only 69 adherents, in the commune of Valcău de Jos.

The protocol of the meeting held on 2 nd September 1948 by the Reformed Council contained two decrees issued by the Grand National Assembly, which dispossessed the church from all of its educational assets. From that moment on, the Reformed church was to be supressed; all the schools and later all the churches became state administered. Alongside churches, other buildings, 
lands and forests were confiscated as well. Thusly, extrareligious activities ceased immediately and Reformed communities were isolated and impoverished. However, despite significant decreases in followers, several local communities like the ones in Izvoru Crișului and Sâncraiu survived relatively intact (Lukács, 2008, p. 125).

The number of Baptists increased compared to 1930 by $10.90 \%$, reaching a percentage of $2.31 \%$ in 2011. In the Bihor Apuseni, in Alessd, the largest Baptist community in the Apuseni Mountains numbered 782 people in 2011. $45.07 \%$ of the regional Baptist community is geographically located in the Bihor Apuseni, while 36.25 \% can be found in the Arad Apuseni. The Baptist faith had basically settled the western part of the Apuseni Mountains, mostly in depression areas ("gulf depressions") (Zărand, Beiuș, Vad-Borod) and between the Western Hills and the mountains.

During the communist period, the Baptist faith received no funds whatsoever from the state budget; moreover, the regime succeeded in controlling Baptist churches and imposed several restrictive measures. The aim was to bankrupt and liquidate the Baptist patrimony, by outlawing churches which might have made mistakes in the management of their financial funds (Ban, 2004 quoted by Bodeanu, 2007, p. 31). Despite the hardships and lack of funds, the number of Baptist followers began to increase in the 1970s. Baptists even managed to prosper with the help of outside aid, mostly from Austria and the Netherlands. After the fall of communism in 1989, Baptists flourished, now unhindered by restrictive policies (Bodeanu, 2007).

By the 2011 census, Roman-Catholics had lost $66.67 \%$ of their regional communities, registering $1.85 \%$. In the Bihor Apuseni, in Aleșd, lives the largest Roman-Catholic community in the Apuseni, with 1.828 adherents, or $25.75 \%$ of all Roman-Catholics in these mountains. The territory once occupied by this denomination gradually shrunk until 2011, only Aleșd surpassing 1.000 people, compared to 1930 when there were four administrative units with more than 1.000 Roman-Catholics. Furthermore, a significant decrease in Roman-Catholic presence took place in the commune of Plopiș, by 67.39 \% (Sălaj Apuseni), where they dominated in 1930. The denomination endured relatively unchanged only in the commune of Șinteu, Bihor Apuseni.

The socialist regime divided the Roman-Catholic Church in two: the priests still loyal to the Holy See and those who collaborated with the new regime. The arrest of Roman-Catholic bishop Áron Marton was the starting point of a restrictive period for this faith. Further arrests and sentences were passed to all of his successors. Their resistance and fight meant that the normal management of religious buildings could no longer be attained. This dark period left its mark by disintegrating religious communities, with repercussions felt even after the fall of communism in 1989. During the democratic period, interest in RomanCatholic values began to fade, local communities grew older, and many adherents began migrating abroad (Zamfir and Nóda, 2008). The result of socialist policies was a significant decrease - $66.67 \%$ - of the regional community of the Apuseni Mountains, recorded at the 2011 census.

The most important religious transformation was the decrease of the GreekCatholic population by $95.69 \%$ between 1930 and 2011, when it reached only 1 $\%$ at regional level. If in 1930 there were administrative units with strong GreekCatholic majorities, in 2011 this denomination no longer held any importance. The largest local community was recorded in Finiș - Bihor Apuseni, comprised of 
461 people, much lower than in 1930, when the largest Greek-Catholic community numbered 6.119 people and was located in Poieni, Cluj Apuseni.

Greek-Catholics began facing extreme hardship in 1948, when (on $1^{\text {st }}$ December), the Greek-Catholic Church was dissolved by decree. During the same year, drastic measures were taken. On 18th July 1948, the Concordat with the Holy See was annulled and on 3rd August, all Greek-Catholic educational institutions were closed. The most brutal measure was the arrest of six GreekCatholic bishops, followed by the closure of all Greek-Catholic monasteries (Soica, 2008, pp. 176-177). Between 27th-30th September 1948, the largest anti Greek-Catholic act perpetrated by the communists took place. Using disinformation and terror, communists made a list of 430 Greek-Catholic clerics who had signed for "the conversion" to Orthodoxism (Moisin, 1998, p. 7). „The signing" of this list struck the local Greek-Catholic communities from the Apuseni Mountains, and alongside with outlawing Greek-Catholicism, it decisively contributed to the disintegration of this church. The list of 430 signatories included clerics from the entire geographic space of the Apuseni Mountains, the destruction of these communities probably being an objective of the regime. The Greek-Catholics had been a community with strong roots in the area since the time of the Habsburgs. Although the Greek-Catholic faith had been reinstated after 1990, the regional community was almost non-existent at the 2011 census, with several local communities entirely gone, such as: Balșa, Băița, Beliș, Bucureșci, Budureasa, Căbești, Căpușu Mare, Curățele, Dezna, Dobrești, Gurahonț, Hălmagiu, Hărău, Hășmaș, Ignești, Izvoru Crișului, Întregalde, Lunca, Măguri-Răcătău, Mărișel, Mogoș, Ocoliș, Petriș, Pietroasa, Pleșcuța, Ponor, Râșca, Roșia, Săvârșin, Șilindia, Șinteu, Șoimi, Tărcaia, Vața de Jos, Vârfurile, and Zam.

Adventism prospered between 1930 and 2011, increasing its "flock" from 122 to 1.141 , or a percentage of $0.30 \%$ in the Apuseni. The Arad Apuseni had $56.53 \%$ of the entire Apuseni area, the largest community being Archiș, with 144 people.

Another growing denomination was Jehova's Witnesses, with no recorded adherents in 1930. After 1989 however, 1.114 people joined this faith. The recorded value of the group was $0.29 \%$ in 2011 . Despite its small size, it is well spread across the Apuseni region, with countless communities of up to 10 people. In Iara, Cluj Apuseni, there were 190 Jehova's Witnesses.

Unitarians went into regress compared to 1930, with a value of $0.23 \%$ in 2011, for the entirety of the Apuseni Region. Rimetea, in the Alba Apuseni, still held the largest community in the area - 89,43\%. Likewise, it has been the only commune with a Unitarian majority, in 1930 as well as 2011.

Another denomination which went through a progressive disappearance was Lutheran, In 2011 there were only 19 Evangelicals in the Apuseni: 13 in Geoagiu, Hunedoara Apuseni, and three people in Gilău and Iara each, in the Cluj Apuseni.

At the 2011 census, three new denominations were recorded, which had not been registered in 1930. However, their numbers are reduced. Evangelicalism had 476 followers, while Old Rite Christians and the Serbian Orthodox numbered 58 and 19 followers respectively.

The second most numerous religion, after Christianity, was Muslim (Islam), with 46 recorded followers in the Apuseni mountain range at the 2011 census. They were distributed across 10 administrative units (Aleșd, Beiuş, Brad, 
Criscior, Geoagiu, Gilău, Ilia, Petriș, Săvârșin, and Vințu de Jos). However, their community is small and scaterred, with little influence on the religious structure and life of these areas.

Table 3. Religious structure of the Apuseni Mountains at the 2011 census (Source: data processed based on National Institute of Statistics)

\begin{tabular}{|c|c|c|c|}
\hline Religions & Religious denominations & Total & Percentage (\%) \\
\hline Christian & Orthodox & 320.894 & 83.69 \\
\cline { 2 - 4 } & Roman-Catholic & 7.099 & 1.85 \\
\cline { 2 - 4 } & Reformed (Calvinist) & 16.474 & 4.30 \\
\cline { 2 - 4 } & Pentecostal & 22.539 & 5.88 \\
\cline { 2 - 4 } & Greek-Catholic & 3.844 & 1 \\
\cline { 2 - 4 } & Baptist & 8.845 & 2.31 \\
\cline { 2 - 4 } & Adventist & 1.141 & 0.30 \\
\cline { 2 - 4 } & Unitarian & 899 & 0.23 \\
\cline { 2 - 4 } & Jehova's Witnesses & 1.114 & 0.29 \\
\cline { 2 - 4 } & Evangelicalism & 58 & 0.12 \\
\cline { 2 - 4 } & Old rite Christian & 19 & 0.02 \\
\cline { 2 - 4 } & Evangelical (Lutheran) & 19 & 0.00 \\
\hline Muslim & Serbian Orthodox & 46 & 0.01 \\
\hline Jewish & & 10 & 0.00 \\
\hline
\end{tabular}

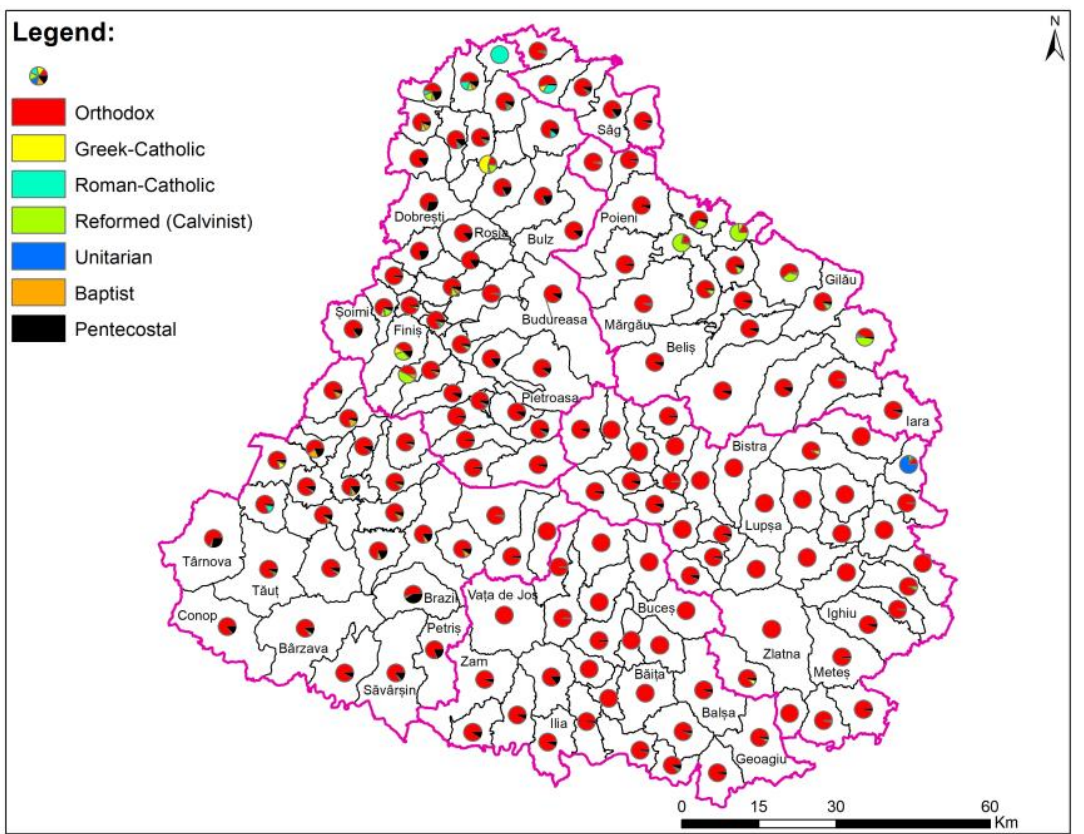

Figure 4. Distribution of religions/confessions for each administrative-territorial unit in 2011 (Source: data processed based on National Institute of Statistics) 
Judaism had faced persecution in the past, standing on the brink of disappearance from the Apuseni mountain space at the 2011 census. In 1930, the Jewish community numbered more than 5.500 people, while in 2011 its numbers decreased to just 10. Persecutions during the war forced many Jews to declare themselves Christian, converting to other denominations such as Reformed and Roman Catholic. Others were arrested and sent to labour / extermination camps. It is clear that political and historical events put their mark on the vanishing of the Jewish faith in the Apuseni Mountains.

The political changes after the end of the Second World War had immediate repercussions on the religious structure of the Apuseni Mountains. These changes were enforced through coercion policies introduced immediately after communists had assumed power. Therefore, Greek-Catholics and RomanCatholics were impacted the most by the religious reforms of the new regime. During the socialist period, the followers of these two denominations decreased in numbers, but were not the only ones to have suffered, as the state promoted atheism altered religious structure, especially Christian faiths. As GreekCatholicism and Roman-Catholicism had been outlawed, many of its followers converted to Orthodoxism, thus increasing Orthodox ranks - $83.69 \%$. An infamous example is the commune of Mărgău, located in the Cluj Apuseni, which, in 1880, had the largest local Greek - Catholic community, comprised of 3.562 people. At the 2011 census, the local community was comprised of only 20 people. Likewise, major mutations took place in Roman-Catholic communities, their numbers decreasing significantly between 1880 and 2011. In 1880, in the old mining town of Roșia Montană, there was a Roman-Catholic community comprised of 1.076 people. Only 57 people had joined this denomination by 2011 .

The Reformed faith also faced difficulties, as it had been replaced in many administrative units as the most numerous denomination. Thusly, until 2011, Reformed kept their standing in only three territorial units: Izvoru Crișului, Sâncraiu and Săvădisla. In the first two communes, consolidated its position reaching local values of $79 \%$, and $76 \%$ respectively, compared to 1880 when they registered only $64 \%$ and $59 \%$. The most significant decrease in the number of Reformed believers from the Apuseni Mountains took place in Huedin, where the census recorded only $28 \%$ in 2011 compared to $78 \%$ in 1880. After the collapse of the communist regime in 1989, the religious structure diversified, new denominations began to arise, while some gained even more believers and followers. It is the case of the Pentecostal Church, which quickly spread in several areas of the Arad and Bihor Apuseni. Likewise, the faith of Jehova's Witnesses managed to form a regional community of 1.114 people, but with a heterogenous distribution across the Apuseni, most local communities having fewer than 50 members.

\section{CONCLUSIONS}

Christianity has dominated the geographic space of the Apuseni Mountains, at each of the three above mentioned population censuses. The dominant element has been Orthodoxism, followed by Greek-Catholicism. Unfortunately, the political factor had a destructive influence on Greek-Catholics after 1948, with the dawn of the communist era. It was the moment when Greek-Catholic representatives were coerced into conversion to Orthodoxism, and their example was followed by their communities. The Austrian-Hungarian 
census of 1880 generated many uncertainties, especially for the Jewish and Orthodox communities. The census recorded 4.900 people of Jewish faith, but no persons of Jewish ethnicity. It is clear that the political-administrative (Austro-Hungarian) factor significantly influenced the census itself, resulting in major errors. At the census held in 2011, the second most numerous denomination in the Apuseni, after Orthodoxism, was Pentecostalism. After the 1989 Revolution, the legislative environment became favourable for the establishment of new religions and denominations. In conclusion, we must point out that Christian-Orthodoxism laid the foundation for the continuity of the Romanian language and the solidification of social ties in the Apuseni Mountains. These strong bonds became apparent through several historical acts of national and international importance, started in the heart of the Apuseni Mountains.

\section{REFERENCES}

Ban, L. (2004). De la ruină la glorie (Eng. From ruin to glory), Editura Carmel Print, Arad.

Basedau, M., Strüver, G., Vüllers, J., \& Wegenast, T. (2011). Do Religious Factors Impact Armed Conflict? Empirical Evidence From Sub-Saharan Africa. Terrorism and Political Violence, 23(5), 752-779.

Bodeanu, D. (2007). Neoprotestanții din Transilvania în timpul regimului comunist (Eng. Transylvanian Neo-Protestants during the Communist Regime), Editura Argonaut, Cluj-Napoca.

Bodeanu, F. (2009). Cultul baptist din Transilvania între 1948-1989 în memoria colectivă. (județele Cluj, Maramureș, Bistrița-Năsăud și Sălaj) (Eng. The Transylvanian Baptist cult between 19481989 in collective memory. (Cluj, Maramureş, Bistrița-Năsăud and Sălaj counties)), Doctoral thesis, Faculty of History and Philosophy, ,,Babeş-Bolyai University” Cluj-Napoca.

Bodocan, V. (2001). Etnie, confesiune si comportament electoral in Transilvania: studiu geografic (Eng. Ethnicity, confession and electoral behaviour in Transylvania: Geographic Study), Editura Presa Universitară Clujeană, Cluj-Napoca.

Crețan, R. (1999). Etnie, confesiune și comportament electoral in Banat: studiu geografic (sfârşitul sec. al XIX-lea ssi sec. al XXlea) (Eng. Ethnicity, confession and electoral behaviour in Banat: geographical study (late 19th and 20th century), Editura Universitatea de Vest, Timișoara.

Filip, CC., \& Matiș, H-D. (2014). Huedinul, o localitate pe drumul spre Europa, aspecte monografice (Huedin, a locality on the Road to Europe, Monographic Aspects), Editura Casa Cărții de Știință, Cluj-Napoca.

Ilieş, Al. (1998). Etnie, confesiune și comportament electoral în Crișana şi Maramureș: (sfârșitul sec. XIX și sec. XX): studiu geografic (Eng. Ethnicity, confession and electoral behaviour in the Crișana and Maramureş: (late 19th and 20th centuries): geographic study), Editura Dacia, Cluj-Napoca.

Ilieş, M., Herman, G., Hodor, N., Baias, Ş., \& Ilieș, A. (2020). The Dynamics, Structure and Spatial Distribution of the Religious Choices of the Romanian Ethnic Community in the Post-Socialist Period (1992-2011). Journal for the Study of Religions and Ideologies, 19(57), 163-185.

King, PE., \& Furrow, J. (2004). Religion as a resource for positive youth development: Religion, social capital, and moral outcomes. Developmental Psychology, 40, 703-713.

Lukács, O. (2008). Scurtă istorie a Bisericii Reformate din Ardeal (Eng. Short History of the Transylvanian Reformed Church). In: Brandes Dieter, Grajdian Vasile, Lukács Olga (Eds.), Scurtă istorie a Bisericilor și Comunităților religioase din Transilvania, Editura Presa Universitară Clujeană, Cluj-Napoca.

Lung, M-S. (2019). Ethnic-confessional cyclicality and continuity in the Petroşani Depression in the period: 1850-2011. Journal of Geography, Politics and Society, 9(1), 12-22. https: / / doi.org/10.26881/jpgs.2019.1.02

Lung, M-S., \& Mureșan, G-A. (2020). Ethnicity and Religion in the Carpathian Mountain Space. Case Study: Mining Centers in the Banat Mountains. Revista Română de Geografie Politică, 22(1), 27-37. https://doi.org/10.30892/rrgp.221104-334

Menjivar, C. (1999). Religious Institutions and Transnationalism: A Case Study of Catholic and Evangelical Salvadoran Immigrants. International Journal of Politics, Culture, and Society, 12(4), 589-612.

Meyer, B. (2009). Introduction: From Imagined Communities to Aesthetic Formations: Religious Mediations, Sensational Forms, and Styles of Binding. In: Meyer Birgit (Eds), Aesthetic Formations. Religion/Culture/Critique, Palgrave Macmillan, New York. 
Moisin, A. (1998). Minciuna „trecerii” la ortodoxie a românilor uniți, greco-catolici, în anul 1948 (Eng. The Lie of "Passing" to Orthodoxism of Greek-Catholic Romanians, in 1948), partea I.

National Institute of Statistics, Population and housing census of 2011.

Olajubu, O. (2004). Seeing through a Woman's Eye: Yoruba Religious Tradition and Gender Relations. Journal of Feminist Studies in Religion, 20(1), 41-60.

Olson, L., Cadge, W., \& Harrison, J. (2006). Religion and public opinion about same-sex marriage. Social Science Quarterly, 87, 340-360.

Pollard, J. (2009). The materialization of religious structures in the time of Stonehenge. Material Religion, 5(3), 332-353.

Rotariu, T-I., Mureşan, C., \& Semeniuc, M. (1997). Recensământul din 1880, Transilvania (Eng. The 1880 Census, Transylvania), Editura Staff, Cluj-Napoca.

Rotariu, T-I., Semeniuc, M., Mezei, E., Moga, M., Somfelean, L., \& Poledna, R. (2011). Recensământul din 1930, Transilvania (Eng. The 1930 Census, Transylvania), Editura Presa Universitară Clujeană, Cluj-Napoca.

Şematismul veneratului cler al Archidiecesei metropolitane greco-catolice române de Alba-Iulia şi Făgăraș pre anul Domnului 1900: de la Sânta Unire 200.

Şişeştean, G. (2002). Etnie, confesiune și căsătorie în nord-vestul Transilvaniei (Eng. Ethnicity, confession and marriage in northwestern Transylvania), Editura Caiete Silvane, Zalău.

Soica, S. (2008). Istoria Bisericii Române Unite cu Roma, Greco-catolică (Eng. History of the Romanian Church United with Rome, Greek Catholic). In: Brandes Dieter, Grajdian Vasile, Lukács Olga (Eds.), Scurtă istorie a Bisericilor și Comunităților religioase din Transilvania, Editura Presa Universitară Clujeană, Cluj-Napoca.

Todd, N., \& Allen, N. (2011). Religious Congregations as Mediating Structures for Social Justice: a Multilevel Examination. Am J Community Psychol, 48, 222-237. https://doi.org/10.1007/s10464-010-9388-8

Tofan, G-B. (2014). The ethnic and confessional structure of Mureș County in 2011. Analele Universității din Oradea, Seria Geografie, 24(1), 14-22.

Tofan, G-B. (2015). Etnie, confesiune şi comportament electoral în județele Harghita, Covasna şi Mureş: studiu geografic (2008-2014) (Eng. Ethnicity, confession and electoral behaviour in Harghita, Covasna and Mureş counties: geographical Study (2008-2014), Editura Casa Cărții de Știință, Cluj-Napoca.

Tofan, G-B., Niță, A., \& Nimară, C. (2014). The Confessional structure of Harghita, Covasna and Mureș Counties, in 2011. Analele Universității din Oradea, Seria Geografie, 24(2), 166-179.

Weightman, B. (1993). Changing Religious Landscapes in Los Angeles. Journal of Cultural Geography, 14(1), 1-20.

Williams, J., \& Wright, J. (2015). The geography of Buddhism in the Four Corners states. Journal of Cultural Geography, 32(3), 304-330.

Wilson, J., \& Janoski, T. (1995). The contribution of religion to volunteer work. Sociology of Religion, $56,137-152$.

Zamfir, K., Nóda, M. (2008). Momentele majore ale istoriei Bisericii Romano-Catolice din Transilvania din perspectiva relatiilor interconfesionale (Eng. Major Moments in the History of the Transylvanian Roman-Catholic Church from the Perspective of Interfaith Relations). In: Brandes Dieter, Grajdian Vasile, Lukács Olga (Eds.), Scurtă istorie a Bisericilor și Comunităților religioase din Transilvania, Editura Presa Universitară Clujeană, Cluj-Napoca.

Submitted:

June 20, 2020
Revised:

September 24, 2020
Accepted and published online: November 27, 2020 